УДК 336.64

DOI: https://doi.org/10.37320/2415-3583/12.32

Кміть В.М.

кандидат економічних наук, доцент кафедри фінансів, грошового обігу і кредиту, Львівський національний університет імені Івана Франка

Бавдик Я.О. студентка, Львівський національний університет імені Івана Франка

\title{
ВПЛИВ ПОДАТКІВ НА СТАН ОБОРОТНОГО КАПІТАЛУ ПІДПРИЕМСТВ УКРАЇНИ
}

У статті досліджено аспекти впливу податків на оборотний капітал підприсмств Украӥни. Опрацювання статистичних даних підтвердило значущість впливу системи оподаткування на структуру оборотного капіталу підприємств України. Наукове дослідження допомогло виокремити основні недоліки в системі фіскальної політики Украӥни, які чинять негативний вплив на господарську діяльність. На основі вищезазначеного запро-

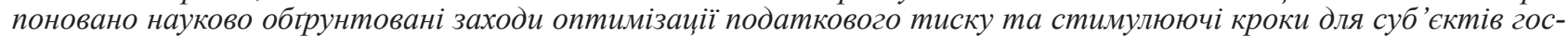
подарської діяльності, щоби спрямувати прибутки підприємств на зростання оборотного капіталу та його структуризацію. Впровадження зазначених пропозицій сприятиме капіталізації фінансових ресурсів для подальшого зростання оборотного капіталу Украӥни, високій ефективності корпоративних фінансів, зростанню позитивних результатів економічної діяльності загалом.

Ключові слова: податки, податкова система, податкове навантаження, фіскальна політика, оборотний капітал, фінансовий результат підприємства.

Постановка проблеми. Податкове навантаження результативний показник фіскальної політики держави, що чинить суттєвий вплив на фінансовий результат роботи підприємств. Від сукупності податків, які треба сплатити, залежить величина фінансових активів, що залишаться у розпорядженні підприємств і слугува- 
тимуть для його подальшого розвитку. Ці фінансові активи дають можливість збільшувати продуктивний капітал та його складник - оборотний капітал [7].

Оборотний капітал сприяє створенню нового продукту та розвитку економічної діяльності окремих підприємств. А це $є$ своєрідним каталізатором розвитку ринків та економічного зростання держави загалом. Вищезазначене слугує основним підтвердженням того, що державна політика та податкове навантаження як іiі результат мають значний вплив не лише на формування і використання оборотного капіталу підприємств, а й на їхній фінансовий стан, функціонування і розвиток.

Аналіз останніх досліджень і публікацій. Проблеми податкового навантаження та його вплив на фінансовий стан підприємств досліджували у своїх працях багато вітчизняних та зарубіжних учених, таких як: В. Вишневський [1], В. Загорський [3], В. Корнус [4], М. Меламед [5], Т. Меліхова [6], Л. Новосельська [7], С. Паранчук [9], А. Соколовська [11], Н. Стеблюк [12] та ін. Попри низку проведених досліджень і численних публікацій, пов'язаних з оборотним капіталом, не всі аспекти цієї проблеми вивчені належним чином. Не досить висвітлено взаємозв'язок фіскальної політики та оборотного капіталу підприємств, у більшості публікацій науковці обмежуються лише твердженнями, що такий зв'язок існує. Тому, коли постає питання, як варто вдосконалювати чинну податкову систему та чи варто знижувати ставку ПДВ, важко дати об'єктивну науково обгрунтовану відповідь. Що стосується процесу адміністрування ПДВ, то він і надалі потребує вдосконалення.

Мета статті полягає у вивченні впливу податкового навантаження на стан оборотного капіталу підприємств та обгрунтування рекомендацій щодо заходів, спрямованих на зниження величини податкового навантаження з метою забезпечення підприємств оборотним капіталом.

Виклад основного матеріалу. Впродовж останніх років економічне та політичне середовище в Україні $\epsilon$ доволі складним і в деяких аспектах непередбачуваним. Саме тому питання економічної безпеки для бізнесу є одним із найактуальніших питань.

Фіскальна політика як один із найефективніших інструментів впливу держави на економіку значною мірою регулює відносини між державою і бізнесом та чинить вплив на ефективність економічної діяльності підприємств. Доведено, що від вибраної державою фіс- кальної політики напряму залежить фінансовий стан підприємств, їхня конкурентоспроможність та успіх на вітчизняному і міжнародних ринках.

$€$ різні підходи до визначення оптимальної величини податкового навантаження та різні міркування стосовно його впливу на економіку. Наприклад, досить відомим є припущення про те, що зростання податків спонукає підприємства до «тінізації» своєї діяльності. Цьому суперечать дослідження М. Меламеда, який на основі статистичних даних спростовує подібне, адже в багатьох досліджуваних випадках спостерігається обернена залежність (високі податки - порівняно нижчий рівень тіньової економіки). Тому на основі цього можна зробити і таке припущення, що саме по собі податкове навантаження $€$ вкрай важливим, проте все ж не вирішальним чинником впливу на розвиток вітчизняної економіки, а тому потребує системного дослідження [6].

Якщо проаналізувати статистику податкових надходжень, то станом на 01.05.2020 р., за даними Мінфіну, найбільшу питому вагу в загальній сумі надходжень до державного бюджету становлять надходження 3 податку на додану вартість (ПДВ) - 33 542,6 млн грн 3 вітчизняних товарів $+78346,5$ млн грн ПДВ з імпортних товарів, що разом становить $46,7 \%$ усіх податкових надходжень державного бюджету та $35,53 \%$ усіх надходжень до державного бюджету за статтями доходів загалом [8], [2] (табл. 1, рис. 1).

Попри те, що Закон України "Про податок на додану вартість" був прийнятий у 1997 році, фахівці стверджують, що таке рішення прийняли, керуючись бажанням пришвидшити вступ в СС, а не об'єктивною економічною доцільністю [1]. Тим не менше ПДВ є одним із фундаментів функціонування вітчизняної економіки, оскільки суттєво розширює межі міжнародної торгівлі. До прикладу, практика використання нульової ставки ПДВ для експортних операцій визнана ефективною в усьому світі, оскільки чинить позитивний вплив на баланс зовнішньої торгівлі.

В Україні ведуться дискусії про доцільність зниження податку на додану вартість (ПДВ). Прихильники зниження ставки ПДВ стверджують, що таке впровадження не лише сприятиме зниженню цін для кінцевого споживача, а і чинитиме позитивний ефект на вітчизняне виробництво та економічний розвиток і стимулюватиме зростання валового внутрішнього продукту. Нещодавно у Верховній Раді зареєстрували

Таблиця 1 - Доходи державного бюджету України станом на 1.05.2020 p. за найбільш вагомими показниками, \%

\begin{tabular}{|l|c|c|}
\hline \multicolumn{1}{|c|}{ Джерело доходів } & Доходи, млн грн. & Частка, \% \\
\hline \multicolumn{1}{|c|}{ ВСБОГО } & $\mathbf{3 1 4 8 4 7 , 3}$ & 11,63 \\
\hline Податок на доходи фізичних осіб & 36624,6 & 11,26 \\
\hline Податок на прибуток підприємств & 35451,1 & 10,65 \\
\hline ПДВ з вітчизняних товарів & 33542,6 & 24,88 \\
\hline ПДВ з імпортних товарів & 78346,5 & 17,69 \\
\hline Інші податкові надходження & 55696,5 & 22,59 \\
\hline Неподаткові надходження & 71133,6 & 1,3 \\
\hline Інше & 4093,0 & \\
\hline
\end{tabular}

Джерело : побудовано на основі [2]

URL: https://index.minfin.com.ua/ua/finance/budget/gov/income/. 


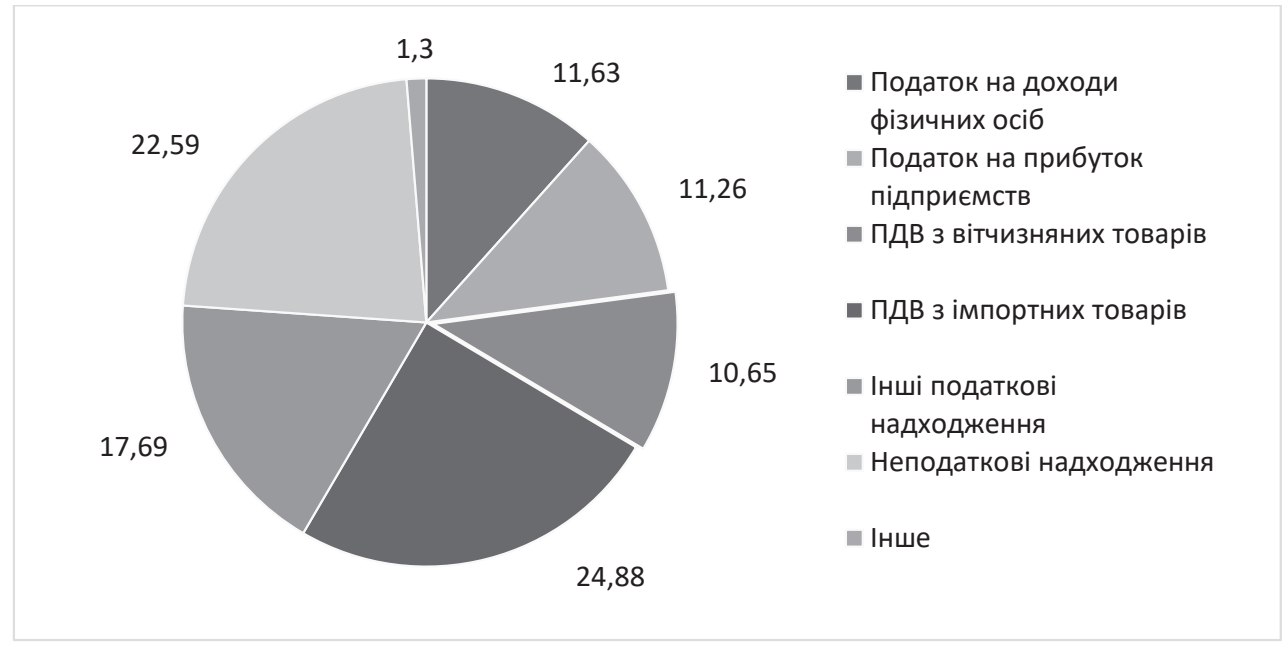

Рисунок 1 - Структура доходів державного бюджету України станом на 1.05.2020 р. за найбільш вагомими показниками, \%

Джерело: побудовано на основі [2]

альтернативний законопроект № 2757-1, яким передбачається поступово зменшувати ставку ПДВ до 15\% протягом 2021-2025 років [10].

Водночас, на думку експертів [13], зниження розміру ставки ПДВ не можна розглядати як вигідний крок для держави, і не варто розраховувати, що зниження ставки ПДВ приведе до зменшення випадків агресивної податкової мінімізації. Адже сьогодні такий спосіб податкової оптимізації вже не є дуже популярним через те, що він $є$ доволі ризикованим, а поряд із ним виникли більш прийнятні, «білі» схеми», які значно частіше використовуються. Більше того, як показує практика та досвід країн $С \mathrm{C}$, проблема полягає не в розмірі ставки ПДВ (у більшості країн СС ставка становить ті самі 20\% або й вище, аж до 27\% в Угорщині), а в неефективності боротьби 3 тіньовими схемами, у недовірі до держави та навіть у менталітеті платника податків. Адже скільки існують податки, незалежно від їх рівня, стільки й існуватиме прагнення платників їх мінімізувати.

На нашу думку, зниження ПДВ є доцільним лише теоретично. Враховуючи сьогоденні реалії, припускаємо, що зменшення ставки ПДВ не призведе до суттєвого зростання виробництва та зниження цін, про що свідчить досвід економічно розвинених країн: суму ПДВ, що вивільняється, підприємці часто трансформують у свої прибутки, не знижуючи ціни і, відповідно, не примножуючи виробництво у зв'язку з тим, що попит залишиться на тому ж рівні за незмінного рівня цін. Отже, значне зниження ставки ПДВ приведе лише до зниження фіскальної частки цього податку в доходах бюджету, тому недоцільно суттєво зменшувати ставки ПДВ.

3 погляду руху оборотного капіталу, податкова система замикає частину кругообігу і відчуває на собі всі тенденції та протиріччя, що склалися у виробничій, монетарній та інституційній сферах [3]. Тому актуальною є проблема бюджетного відшкодування. В Україні доволі поширеними $є$ фіктивні зовнішньоекономічні операції, кінцевою метою яких є незаконне отримання відшкодування ПДВ з бюджету. Це призводить до значної заборгованості та неспроможності відшкодувати ПДВ реальним вітчизняним експортерам, що викликає обурення та обгрунтовані претензії до Державної податкової служби України (ДПСУ), оскільки такі дії можна розглядати як несанкціоноване заморожування оборотного капіталу підприємств. Водночас поточна система адміністрування ПДВ характеризується відсутністю комплексного підходу до його обліку, контролю і доступу до інформації. ДПСУ та Державне казначейство діють розрізнено, не координуючи своїх зусиль для належного державного впливу на підвищення ефективності цього важливого чинника поповнення оборотного капіталу.

Суперечливість та складність механізму справляння ПДВ викликає низку дискусій, тому загалом вплив цього податку на стан оборотного капіталу важко переоцінити. Грунтовну теоретичну оцінку впливу ПДВ на господарську діяльність та оборотний капітал вітчизняних підприємств необхідно доповнювати кількісними дослідженнями, розрахунками та складними математичними моделями. Але що стосується загальних проблем, пов'язаних із ПДВ, то підприємства залишаються невдоволеними зниженням оборотності коштів, складністю адміністрування та значними витратами на супроводження податку [9].

Вчені, що вважають ПДВ доцільним та ефективним, доводять його позитивний вплив на фінансовий стан підприємств. Наприклад, те, що ПДВ є своєрідним інструментом примусового безкоштовного кредитування підприємств споживачами [4]. Це виникає як результат того, що підприємства мають відтермінування щодо перерахування ПДВ, тобто вони можуть використовувати суми вхідного ПДВ як безвідсотковий кредит. Проте, порівнюючи терміни сплати ПДВ та терміни реального його відшкодування, можна дійти висновку, що наявність на рахунках коштів, які $\epsilon$ податковим кредитом, навряд чи сприймається підприємствами як вільні кредитні ресурси, що мають на меті покращення ефективності фінансово-господар- 
ської діяльності, позитивно впливаючи на оборотність коштів підприємства та його стан.

Що стосується інших податків і зборів, то тут варто зазначити, що важливим напрямом дієвої фіскальної політики $\epsilon$ забезпечення раціонального податкового адміністрування, а також орієнтація на повне виконання фіскального законодавства усіма платниками, у тому числі й державними органами. Варто передбачити податкові пільги для підприємств, які спрямовують (інвестують) прибуток у примноження власної капітальної бази, у тому числі в частині збільшення оборотного капіталу [12]:

- запровадження зниженої ставки податку на прибуток підприємств, який вкладається у поповнення оборотного капіталу;

- запровадження податкового відстрочення та розстрочення суб'єктів корпоративного сектору, які працюють у капіталомістких видах економічної діяльності і при цьому вкладають фінансові ресурси в поповнення оборотного капіталу;

- встановлення пріоритетного права на відшкодування ПДВ підприємствами, які працюють у «працемістких» видах економічної діяльності з високою часткою оборотного капіталу в загальній структурі капіталу (легка промисловість, харчова промисловість, виробництво послуг тощо);

- надання «податкових канікул» підприємствам, які вкладають фінансові ресурси у нарощування оборотного капіталу.

Донедавна одним із найефективніших інструментів фіскальної політики прийнято було вважати пільгове оподаткування. Проте, як показує вітчизняна та іноземна практика, часто фінансові ресурси, що вивільняються внаслідок застосування пільгового оподаткування, спрямовуються не на формування оборотного капіталу та зародження нових виробничих циклів, а для нагромадження фінансових активів 3 метою їх подальшого виведення в офшорні зони. Для усунення цього недоліку варто запровадити норму, відповідно до якої податкові пільги надаються підприємствам виключно на підставі вимог законодавчих актів і нормативних документів, а також спеціального договору, що укладатиметься між контролюючими органами та платниками податків. Відповідно до умов цього договору, платник податків добровільно бере на себе зобов'язання спрямувати вивільнені в результаті звільнення від оподаткування фінансові ресурси лише на поповнення оборотного капіталу 3 подальшим його використанням для підтримки наявного або створення нового виробництва.

Що стосується фіскальної політики підприємств, то правильно спрямована політика на підприємстві $є$ незмінним і надійним механізмом захисту від податкових ризиків [11]. Ефективне управління податковими ризиками - це одна з ключових умов успішного бізнесу. Для того щоб дати платникам податків можливість самостійної оцінки податкових ризиків, Міністерство фінансів України затвердило Порядок формування плану-графіка проведення документальних планових перевірок платників податків.

До плану-графіка включаються платники податків, які за результатами господарської діяльності мають найбільші ризики несплати в бюджет податків і зборів. Нормативний акт розмежовує платників податків за ступенем ризиковості: високий, середній та незначний ризик.

Висновки. Отже, податки є не лише інструментом формування доходів держави та місцевих бюджетів, але й потужним важелем впливу на фінанси підприємств та їхній подальший розвиток. Виявлено, що натепер фіскальна політика не сприяє вирішенню проблем нарощування капітальної бази бізнесу, у тому числі в частині акумуляції оборотного капіталу.

Можливим варіантом оновлення податкової системи України слід вважати застосування зазначених методів зниження податкового навантаження на оборотний капітал, який безпосередньо бере участь у створенні доданої вартості. Це має обов'язково привести до позитивних макроекономічних змін, а також чинитиме позитивний вплив на розвиток окремих підприємств.

\section{Список використаних джерел:}

1. Вишневський В. Принципи оподаткування: обгрунтування і емпірична перевірка. Економіка Украӥни. 2008. № 10. С. 55-59.

2. Доходи державного бюджету України за статтями доходів в 2020 p. URL : https://index.minfin.com.ua/ua/finance/budget/ gov/income/ (дата звернення: 9.05.2020).

3. Загорський В. Концептуалізація сучасних підходів до реформування податкової системи України. Регіональна економіка. 2006. № 2. С. 36-43.

4. Корнус В. Податкове навантаження та купівельна спроможність населення в економіці України. Bicник НБУ. 2008. № 7. C. 35-49.

5. Меламед М.Я. Валовий внутрішній продукт України та його податковий потенціал. Вісник Начіонального банку України. 2005. № 6. С. 18-27

6. Меліхова Т.О. Удосконалення методів аналізу податкового навантаження господарської діяльності підприємств. Наукові прачі КНТУ: Економічні науки. 2010. № 17. С. 248-255.

7. Новосельська Л.І. Методи оцінювання рівня податкового навантаження. Науковий вісник ЛНТУ Украӥни. 2013. № 23. С. 239-244.

8. Офіційний сайт Державної служби статистики України. URL : http://www.ukrstat.gov.ua (дата звернення: 9.05.2020).

9. Паранчук С.В. Вплив фіскальної політики на стан оборотного капіталу в корпоративному секторі. БізнесІнформ. 2014. № 2. URL: http://www.irbis-nbuv.gov.ua/cgi-bin/irbis_nbuv/cgiirbis_64.exe (дата звернення: 9.05.2020).

10. Ставку ПДВ пропонують поступово зменшити до 15\%: черговий законопроект. Дебет-Кредит : веб-сайт. URL: https://news.dtkt.ua/taxation/pdv/60510 (дата звернення: 9.05.2020).

11. Соколовська А.М. Теоретичні засади визначення податкового навантаження та рівня оподаткування економіки. Економіка Украӥни. 2006. № 7. С. 4-12.

12. Стеблюк Н.Ф. Вплив податкового навантаження на діяльність підприємств. Молодий вчений. Частина 1.2015. № 8(23). C. $80-86$.

13. Що дасть зниження ПДВ? Економічні новини : веб-сайт. 2018. URL: https://enovosty.com/uk/ekonomika-ukr/full/1007shho-dast-znizhennya-pdv (дата звернення: 9.05.2020). 


\section{References:}

1. Vyshnevsky V. (2008) Pryntsypy opodatkuvannya: obgruntuvannya i empirychna perevirka [Principles of taxation: justification and empirical verification]. Ekonomika Ukrayiny, no. 10. pp. 55-59 [in Ukrainian].

2. Revenues of the state budget of Ukraine in 2020 : web-site. URL: https://index.minfin.com.ua/ua/finance/budget/gov/income/ [in Ukrainian].

3. Zagorsky V. (2006) Kontseptualizatsiya suchasnykh pidkhodiv do reformuvannya podatkovoyi systemy Ukrayiny [Conceptualization of modern approaches to reforming the tax system of Ukraine]. Rehional'na ekonomika, no. 2, pp. 36-43 [in Ukrainian].

4. Kornus V. (2008) Tax burden and purchasing power of the population in the economy of Ukraine. Visnyk NBU, no. 7, pp. 35-49 [in Ukrainian].

5. Melamed, M. (2005) Valovyy vnutrishniy produkt Ukrayiny ta yoho podatkovyy potentsial [Gross domestic product of Ukraine and its tax potential]. Visnyk Natsional'noho banku Ukrayiny. Visnyk Natsional'noho banku Ukrayiny, no.6, pp. 18-27 [in Ukrainian].

6. Melikhova T. (2010) Udoskonalennya metodiv analizu podatkovoho navantazhennya hospodars'koyi diyal'nosti pidpryyemstv [Improvement of methods of analysis of tax burden of economic activity of enterprises]. Scientific works of KNTU: Economic sciences, no.17, pp.248-255 [in Ukrainian].

7. Novoselskaya L. (2013) Metody otsinyuvannya rivnya podatkovoho navantazhennya [Methods for assessing the level of tax burden]. Naukovyy visnyk LNTU, vol. 10, no. 23, pp. 239-244. [in Ukrainian]

8. Official site of the State Statistics Service of Ukraine : web-site. URL: http://www.ukrstat.gov.ua/ [in Ukrainian]

9. Paranchuk S. (2014) Vplyv fiskal'noyi polityky na stan oborotnoho kapitalu v korporatyvnomu sektori [Influence of fiscal policy on the state of working capital in the corporate sector]. BiznesInform. URL: http://www.irbis-nbuv.gov.ua/cgi-bin/irbis_nbuv/ cgiirbis_64.exe [in Ukrainian].

10. The VAT rate is proposed to be gradually reduced to 15\%. 2020. Debit Credit-web-site. URL: https://news.dtkt.ua/taxation/ $\mathrm{pdv} / 60510$ [in Ukrainian].

11. Sokolovskaya A. (2006) Teoretychni zasady vyznachennya podatkovoho navantazhennya ta rivnya opodatkuvannya ekonomiky [Theoretical principles of determining the tax burden and the level of taxation of the economy]. Ekonomika Ukrayiny, no. 7, pp. 4-12. [in Ukrainian].

12. Steblyuk N. (2015) Vplyv podatkovoho navantazhennya na diyal'nist' pidpryyemstv [Influence of tax burden on the activity of enterprises]. Molodyy vchenyy, vol. 8, no. 23, pp. 80-86 [in Ukrainian].

13. What is affected by the reduction of VAT? (2018) Economic news : web-site. URL: https://enovosty.com/en/economics-ukr/ full/1007-shho-dast-znizhennya-pdv [in Ukrainian].

Kmit Vira, Bavdyk Yaryna

Ivan Franko National University of Lviv

\section{THE TAXES INFLUENCE ON WORKING CAPITAL}

Working capital contributes to the creation of a new product and the development of economic activity of individual enterprises. In turn, this works as a catalyst for market development and economic growth in general. Mentioned above is the main confirmation that government policy and the tax burden have a significant impact not only on the formation and use of enterprises working capital, but also on their financial results, their operation and development. The main goal of the article is to find out more about the impact of taxes on the enterprises working capital and to develop on this basis recommendations. Despite a huge number of studies and numerous publications, not all aspects of the taxes impact on businesses have been studied, as well as some issues relevant to Ukraine in today's realities remain unresolved. For example, there are no generally accepted methodological approaches to calculating the tax rate in Ukraine, as a result of which scientists operate with different indicators, which leads to contradictory conclusions, and thus complicates the adoption of scientifically sound management decisions and effective tax policy. Assessment of the impact of the tax burden on the financial and economic activities of enterprises will allow forming recommendations for optimizing the tax burden as one of the main ways to improve the financial condition of the enterprise. Some aspects of the national taxes impact on working capital of Ukrainian enterprises are examined. Ways of the working capital of individual enterprises improvement in order to improve the domestic business environment in general are identified, as well as ways to increase working capital by domestic businesses. Based on the mentioned above, there are some ways to optimize the tax burden and incentives for businesses to direct the profits of enterprises to the growth of working capital and its structuring. The implementation of these proposals will contribute to the capitalization of financial resources for further growth of working capital of Ukraine, high efficiency of corporate finance, the growth of positive results.

Key words: taxes, tax system, tax burden, fiscal policy, working capital, financial result of the enterprise.

JEL classification: G32, G38, H25, H26, H32 